\title{
Nitrogen induced DOC and heavy metals leaching: Effects of nitrogen forms, deposition loads and liming ${ }^{\text {is }}$
}

\author{
Afia Zia ${ }^{\text {a, b }}$, Leon van den Berg ${ }^{\text {b, c }}$, Muhammad Riaz ${ }^{\text {b, d, * }}$, Muhammad Arif e, Dania Zia ${ }^{\text {, }}$ \\ Shawana J. Khan ${ }^{a}$, Muhammad Nauman Ahmad ${ }^{a}$, Attaullah ${ }^{a}$, Mike Ahsmore ${ }^{b}$ \\ a Department of Agricultural Chemistry, The University of Agriculture Peshawar, Khyber Pakhtunkhwa, Pakistan \\ b Department of Environment and Geography, University of York, Heslington, York, YO10 5NG, UK \\ ${ }^{c}$ Aquatic Ecology \& Environmental Biology, Radboud University Nijmegen, the Netherlands \\ ${ }^{\mathrm{d}}$ Department of Environmental Sciences \& Engineering, Government College University Faisalabad, 38000, Faisalabad, Pakistan \\ e Directorate of Outreach, Agricultural Research System, Govt of Khyber Pakhtunkhwa, Peshawar, Pakistan \\ ${ }^{\mathrm{f}}$ Department of Biotechnology, Quaid-i-Azam University Islamabad, Pakistan
}

\section{A R T I C L E I N F O}

\section{Article history:}

Received 20 April 2020

Received in revised form 30 May 2020

Accepted 4 June 2020

Available online 10 June 2020

\section{Keywords:}

DOC

Nitrogen load

Heavy metal leaching

Liming

\begin{abstract}
A B S T R A C T
Atmospheric nitrogen $(\mathrm{N})$ deposition is believed to accelerate dissolved organic carbon (DOC) production and could lead to increased heavy metal mobility into water resources. We sampled intact soil cores from the Isle of Skye with low background N deposition history and having Serpentine rock known for its higher heavy metal concentrations including zinc $(\mathrm{Zn})$, copper $(\mathrm{Cu})$, nickel $(\mathrm{Ni})$ and lead $(\mathrm{Pb})$. The effects of $16(16 \mathrm{kgN})$ and $32 \mathrm{~kg} \mathrm{~N} \mathrm{ha}^{-1}$ year $^{-1}(32 \mathrm{kgN})$, and liming with $32 \mathrm{kgN}(32 \mathrm{kgN}+$ Lime) on soil solution chemistry and heavy metal mobilization were investigated over the 15-month study. Nitrogen in deposition load was added at five ammonium $\left(\mathrm{NH}_{4}^{+}\right)$to nitrate $\left(\mathrm{NO}_{3}^{-}\right)$ratios of 9:1, 5:1, 1:1, 1:5 and 1:9 along $\mathrm{NO}_{3}^{-}$dominance. We found significant effects of load on $\mathrm{Cu}$ and $\mathrm{NH}_{4}^{+} / \mathrm{NO}_{3}^{-}$ratio on $\mathrm{pH}, \mathrm{DOC}$ and $\mathrm{Zn}$ in soil solution. However, under lime and ratio experimental factors, liming significantly influenced $\mathrm{pH}$, DOC, $\mathrm{Cu}$ and $\mathrm{Pb}$, and $\mathrm{NH}_{4}^{+} / \mathrm{NO}_{3}^{-}$ratio $\mathrm{pH}, \mathrm{DOC}, \mathrm{Ni}$ and $\mathrm{Zn}$ whereas interactions between lime and ratio was significant for $\mathrm{Ni}$ and $\mathrm{Cu}$. pH and $\mathrm{DOC}$ increased with $\mathrm{N}$ load, liming and $\mathrm{NO}_{3}^{-}$dominance, and both correlated significantly positively. Liming under $\mathrm{NH}_{4}^{+}$dominance enhanced DOC production due to supply of base cations in lime. Mobilization of $\mathrm{Cu}, \mathrm{Ni}$ and $\mathrm{Pb}$ was driven by $\mathrm{DOC}$ concentrations and, therefore, increased with load, liming and $\mathrm{NO}_{3}^{-}$dominance in deposition. However, in contrast, low pH and high $\mathrm{NH}_{4}^{+}$dominance was associated with $\mathrm{Zn}$ mobilization in soil solution. On the contrary, despite of some patterns, heavy metals in soil $\mathrm{HNO}_{3}$ extracts were devoid of any load, lime and $\mathrm{NH}_{4}^{+} / \mathrm{NO}_{3}^{-}$ratio effects. Our study suggests that the effects of $\mathrm{N}$ load and forms in deposition on sites with high accumulated loads of metals need to be better quantified through soil solution partitioning models.
\end{abstract}

() 2020 Elsevier Ltd. All rights reserved.

\section{Introduction}

The global nitrogen $(\mathrm{N})$ cycle has dramatically changed since the onset of industrial N fixation in 1909 (Galloway et al., 1995; Ussiri and Lal, 2013; Erisman et al., 2018). Total N deposition to nonforest ecosystems in the UK showed a larger spatial variation and ranged from high $\left(25-35 \mathrm{~kg} \mathrm{~N}^{-1} \mathrm{yr}^{-1}\right)$ to very low $(3-5 \mathrm{~kg} \mathrm{~N}$ $\mathrm{ha}^{-1} \mathrm{yr}^{-1}$ ) (Andersson et al., 1994a). Nitrogen deposition in the

\footnotetext{
* This paper has been recommended for acceptance by Jörg Rinklebe.

* Corresponding author. Department of Environmental Sciences \& Engineering, Government College University Faisalabad, 38000, Faisalabad, Pakistan.

E-mail address: mr548@ymail.com (M. Riaz).
}

United Kingdom (UK) fell by about 15\% between 1988 and 2008, but it was unclear if soil processes were recovering due to decrease in $\mathrm{N}$ deposition, as the highest rates of $\mathrm{N}$ emissions and deposition dominated for four consecutive decades in the $20^{\text {th }}$ century (Fowler et al., 2004a; Oenema et al., 2011; RoTAP, 2012). According to the scenario analyses, the European areas at risk from the $\mathrm{N}$ deposition would decrease from $75 \%$ (in 1980) to 55\% (in 2020) under the amended Gothenburg Protocol (Maas and Grennfelt, 2016). Thus, in 2020 more than $50 \%$ of the European Nature In-formation System (EUNIS) classified ecosystem areas are still expected to face the risk of excessive nutrient $\mathrm{N}$ deposition (EEA, 2014a). This decline appears to be late to prevent and fully converse the destruction caused by the elevated $\mathrm{N}$ deposition of $3000-5000 \mathrm{~kg} \mathrm{~N} \mathrm{ha}^{-1}$ from 
1900 to 2000 in the most N-polluted regions of the UK (Fowler et al., 2004b). Despite the considerable decreases in $\mathrm{N}$ emissions (Matejko et al., 2009), the future deposition rates modelled for 2020 suggests that critical $\mathrm{N}$ loads will continue to exceed in about half the area of the most sensitive ecosystems in the UK (Matejko et al., 2009; RoTAP, 2012; Bobbink et al., 2015).

Nitrogen deposition occurs in two major forms: a reduced, mainly as ammonia $\left(\mathrm{NH}_{3}\right)$ or ammonium $\left(\mathrm{NH}_{4}^{+}\right)$and an oxidized form dominated by nitrate $\left(\mathrm{NO}_{3}^{-}\right)$(Aneja et al., 2001). While, the emissions of oxidized $\mathrm{N}$ in the UK declined by $58 \%$ during the 1988-2008 period, those of reduced $\mathrm{N}$ only declined by $21 \%$ (RoTAP, 2012). High emissions of reduced $\mathrm{N}$ are associated with regions of intensive agricultural activities, while regions of high emissions of oxidized $\mathrm{N}$ are associated with high vehicular and/or industrial activities (Decina et al., 2020). Hence. The proportion of $\mathrm{N}$ deposition that is in the oxidized or reduced form shows strong spatial variations across the UK and other European countries, and is also changing over time (van den Berg et al., 2016). For example, the UK shows a large spatial range in $\mathrm{NH}_{4}^{+} / \mathrm{NO}_{3}^{-}$deposition ratios, from $0.3 \mathrm{~mol} \mathrm{~mol}^{-1}$ to $3 \mathrm{~mol} \mathrm{~mol}^{-1}$ (Fowler et al., 2004a). It is, therefore, imperative to understand the effects of different forms of $\mathrm{N}$ deposition on soil biogeochemical processes, toxicity mechanisms and ecosystem functions (Sheppard et al., 2004; Huang et al., 2015; Chen et al., 2016). Such improved understanding would allow sites and habitats at greatest risk to be more reliably identified, and hence, provide a greatly effective evidence base to adopt better protection measures (Stevens et al., 2011; Li et al., 2016). Different N forms may have differential direct and indirect effects on $\mathrm{N}$ sensitive vegetation such as bryophytes and vascular plants resulting from preferential uptake mechanisms, toxicity and through changes in soil chemistry (Fleischer et al., 2015; Binkley and Hogberg, 2016).

Soil acidification and soil buffering capacity, measured as the acid neutralizing capacity (ANC), are considered to play an important role in defining the soil-plant responses to $\mathrm{N}$ deposition. Moreover, $\mathrm{N}$ mobility is partly driven by dissolved organic carbon (DOC), which is a potentially significant mechanism of $C$ export from the soil system under highly organic conditions (Kaiser, 2001; Jiang et al., 2016). Atmospheric $\mathrm{N}$ deposition may be associated with the increased DOC production through increased microbial activity which can facilitate transport of metals through formation of DOC-metal complexes (Yang et al., 2013; Hu et al., 2018). Hence, increased $\mathrm{N}$ deposition may result in increased metal transport to deeper ground water layers (Stevens et al., 2009). The soils with high metal concentrations, slightly acidified and depleted of base cations, may be expected to experience higher metals concentrations in soil solution through both the decreased $\mathrm{pH}$ and the increased DOC concentrations (Tipping and Hurley, 1992; Jones, 1998; Goulding, 2016).

The objectives of this greenhouse mesocosm study were to investigate the effects of two $\mathrm{N}$ deposition loads, $16(16 \mathrm{kgN})$ and $32 \mathrm{~kg} \mathrm{ha}^{-1}$ year $^{-1}(32 \mathrm{kgN})$ applied as five ammonium to nitrate $\left(\mathrm{NH}_{4}^{+}: \mathrm{NO}_{3}^{-}\right)$ratios and liming, at high $\mathrm{N}$ load $(32 \mathrm{kgN}+$ Lime), on changes in soil solution chemistry and their influence on nickel $(\mathrm{Ni})$, copper $(\mathrm{Cu})$, zinc $(\mathrm{Zn})$ and lead $(\mathrm{Pb})$ in porewater. Our core hypothesis was that the changes in soil solution $\mathrm{pH}, \mathrm{DOC}, \mathrm{NH}_{4}^{+}$and $\mathrm{NO}_{3}^{-}$would mobilize $\mathrm{Ni}, \mathrm{Cu}, \mathrm{Zn}$ and $\mathrm{Pb}$ differently because:

1) $\mathrm{Cu}$ and $\mathrm{Pb}$ are primarily associated with $\mathrm{DOC}$ and their concentrations in porewater are higher when $\mathrm{NO}_{3}^{-}$dominates $\mathrm{N}$ deposition load; and,

2) $\mathrm{Ni}$ and $\mathrm{Zn}$ increase with acidity and, therefore, Ni and $\mathrm{Zn}$ concentrations in porewater are higher when $\mathrm{NH}_{4}^{+}$is dominant in deposition.

\section{Materials and methods}

\subsection{Study site characteristics}

The intact monoliths for this greenhouse study were selected from the Isle of Skye, Scotland $\left(57.2736^{\circ} \mathrm{N}, 6.2155^{\circ} \mathrm{W}\right.$; UK grid ref: GR 408224). The site has long low $\mathrm{N}$ deposition history of receiving an estimated $1-3 \mathrm{~kg} \mathrm{~N}^{-1}$ year $^{-1}$. The mean monthly temperature at the site is $8.5^{\circ} \mathrm{C}$ and has $112 \mathrm{~mm}$ mean monthly rainfall whereas the total rainfall at the site is $1348 \mathrm{~mm}$. The underlying rock is serpentine in the area known for higher concentrations of heavy metals including $\mathrm{Cu}, \mathrm{Ni}, \mathrm{Zn}$ and chromium (Alexander, 2004). This site, therefore, provided a unique opportunity to develop an experimental set-up to test our hypothesis that $\mathrm{NH}_{4}^{+}$and $\mathrm{NO}_{3}^{-}$ deposition have differential effects on heavy metal leaching through changes in soil solution $\mathrm{pH}$ and DOC.

\subsection{Intact core samplings and greenhouse experiment}

The mesocosms for this study were developed by collecting intact monoliths, including both the soil and vegetation, in April 2009 from a wet-heath site (NVC M15 wet heath) on the Isle of Skye, UK $\left(57.2736^{\circ} \mathrm{N}, 6.2155^{\circ} \mathrm{W}\right)$. Within uniform patch of M15 vegetation area, 96 PVC cores ( $25 \mathrm{~cm}$ height and $20 \mathrm{~cm}$ diameter) were inserted into the peat while avoiding any damage to the vegetation. The monoliths were excavated to get intact peat cores with vegetation which were taken to greenhouse facilities at the York University $\left(53.9461^{\circ} \mathrm{N}, 1.0518^{\circ} \mathrm{W}\right.$ ) for the mesocosm experiment. The greenhouse was selected to avoid outside variations in temperature and, because of generally warmer conditions in glass house, evaporation was controlled by watering with distilled water, especially in summer months. Soil monoliths, with intact vegetation, were fitted into a plastic bottom with outlet to maintain porewater levels at $5 \mathrm{~cm}$ below field level. Each core was fitted with a Rhizon samplers (Eijkelkamp, The Netherlands) at $10 \mathrm{~cm}$ below the surface of core. Nitrogen deposition was simulated using ammonium chloride $\left(\mathrm{NH}_{4} \mathrm{Cl}\right)$ for $\mathrm{NH}_{4}^{+}$and sodium nitrate $\left(\mathrm{NaNO}_{3}\right)$ for $\mathrm{NO}_{3}^{-}$in artificial rainwater which was applied three times a week. Artificial rainwater contained deionised water with macroand micro-nutrients at background concentrations: $66 \mu \mathrm{mol} \mathrm{L}{ }^{-1}$ $\mathrm{Na}^{+}, 77.5 \mu \mathrm{mol} \mathrm{L}{ }^{-1} \mathrm{Cl}^{-}, 7.5 \mu \mathrm{mol} \mathrm{L}{ }^{-1} \mathrm{Mg}^{2+}, 4 \mu \mathrm{mol} \mathrm{L}{ }^{-1} \mathrm{SO}_{4}^{2-}$, $1.5 \mu \mathrm{mol} \mathrm{L}^{-1} \mathrm{Ca}^{2+}$ and $1.4 \mu \mathrm{mol} \mathrm{L}^{-1} \mathrm{~K}^{+}$(van den Berg et al., 2005). Five different $\mathrm{NH}_{4}^{+} / \mathrm{NO}_{3}^{-}$ratios of 1:9,1:5,1:1, 5:1 and 9:1 (mol:mol) were tested in simulated atmospheric $\mathrm{N}$ deposition at two $\mathrm{N}$ loads of $16(16 \mathrm{kgN})$ and $32 \mathrm{~kg} \mathrm{~N} \mathrm{ha}^{-1}$ year $^{-1}(32 \mathrm{kgN})$. These $\mathrm{N}$ deposition loads represented a gradient in ammonium dominance to nitrate dominance and corresponded to the critical $\mathrm{N}$ load and the highest ambient $\mathrm{N}$ deposition rates in the UK for this ecosystem. In addition, these five $\mathrm{NH}_{4}^{+} / \mathrm{NO}_{3}^{-}$ratios were also tested at a fixed $\mathrm{N}$ deposition load of $32 \mathrm{~kg} \mathrm{~N}^{-1}$ year $^{-1}$ with a lime ( $32 \mathrm{kgN}+$ Lime) $\left(\mathrm{CaCO}_{3} 80 \%, \mathrm{MgCO}_{3} 10 \%\right)$ added at $100 \mathrm{~g} \mathrm{~m}^{-2}$ rate as a powder to the soil surface at the start of the experiment. Lime was only added once, assuming that it was enough to compensate for base cation depletion throughout the experiment without changing the soil $\mathrm{pH}$ too much. In this fully factorial experimental design, each treatment was replicated six times and experiment consisted of 90 intact monoliths in total (Table S1).

\subsection{Soil solution sampling and analysis}

Porewater samples were taken with rhizone samplers, fitted at $10 \mathrm{~cm}$ depth, six times (June 2009, September 2009, January 2010, April 2010, July 2010, and September 2010) over the 15-month experiment from June 2009 to Sep 2010. Soil solution pH were measured with a pre-calibrated Thermo Orion 420 pH meter (Riaz 
et al., 2009).

The porewater samples were analyzed for $\mathrm{NH}_{4}^{+}-\mathrm{N}$ and $\mathrm{NO}_{3}^{-}-\mathrm{N}$ concentrations on an auto-analyzer (Bran + Luebbe Auto Analyzer 3, Germany) using a matrix-matched standards protocol within $24 \mathrm{~h}$ of collection. Ammonium nitrate standards of $0,0.5,1.0,1.5$, and $2.0 \mathrm{mg} \mathrm{L}^{-1}$ were prepared in distilled water and $2.0 \mathrm{ppm}$ standard was always used as drift standard.

Concentrations of DOC in soil solution samples were determined using a TOC elemental analyzer (Elementar Analysensysteme $\mathrm{GmbH}$, Hanau, Germany). Prior to analysis, samples were filtered through $0.45 \mu \mathrm{m}$ Whatman membrane filter papers. Basic stock solution containing $500 \mathrm{mg} \mathrm{L}^{-1}$ TIC (sodium carbonate as TIC standard) and $500 \mathrm{mg} \mathrm{L}^{-1}$ TOC (potassium phthalate as the TOC standard) was prepared. Intermediate stock solutions were prepared to produce calibration standards having $1,2.5,5,10,20$, and $50 \mathrm{mg} \mathrm{L}^{-1}$ DOC concentrations.

The soil solution samples for metal analysis were acidified by adding $100 \mu \mathrm{L} 70 \%$ nitric acid $\left(\mathrm{HNO}_{3}\right)$ to every $10 \mathrm{~mL}$ sample so precipitation in the samples was avoided and samples were storing at $4{ }^{\circ} \mathrm{C}$ until analysis.

\subsection{Soil sampling and digestion}

Soil samples from the 36 cores received $16 \mathrm{kgN}, 32 \mathrm{kgN}$ and $32 \mathrm{kgN}+$ Lime at 9:1 and 1:9 $\mathrm{NH}_{4}^{+} / \mathrm{NO}_{3}^{-}$ratios were taken in October cutting at least $70 \mathrm{~g}$ fresh soil from the top $15 \mathrm{~cm}$ of peat in each core. The soil samples were transferred to the laboratory in an ice box and stored at $4{ }^{\circ} \mathrm{C}$ until analysis. Soils were stored in airtight plastic bags, from which as much air as possible was removed. The roots and shoots were removed and soils were mixed thoroughly by hand for homogenized samples to avoid internal variation between sub samples. Ten-gram of these soil subsamples were dried in an oven at $105{ }^{\circ} \mathrm{C}$ and ground into fine-powder using a Retsch MM400 Ball Mill (Retsch GmbH, Germany). Acid digestion was carried out by adding $4 \mathrm{~mL} 65 \%$ nitric acid $\left(\mathrm{HNO}_{3}\right)$ and $1 \mathrm{~mL} 30 \%$ hydrogen peroxide $\left(\mathrm{H}_{2} \mathrm{O}_{2}\right)$ to 200 -mg of each sample in a Milstone microwave (type MLS 1200 mega, Milstone Inc., Sorisole, Italy) following procedure described by Zia et al. (2018). After filtering through Whatman\#42 filter papers, digests were diluted with deionised water to $100 \mathrm{~mL}$ volume and kept at $4{ }^{\circ} \mathrm{C}$ until analysis.

\subsection{Analysis of heavy metals}

Concentrations of $\mathrm{Ni}, \mathrm{Cu}, \mathrm{Zn}$ and $\mathrm{Pb}$ were analyzed on ICP-MS and ICP-OES. Zn, was determined using an ICP Spectrometer (IRIS Intrepid II, Thermo Electron Corporation, USA) whereas $\mathrm{Ni}, \mathrm{Cu}$ and $\mathrm{Pb}$ were analyzed using ICP Spectrometer (X series; Thermo Fisher Scientific, Waltham, MA, U.S.A). Blanks were used to correct for extraction buffer quality and reference solutions for quality checks on the concentrations. Where the blank values were significantly above zero, they were subtracted from the measured values. The drift and QC control were achieved by the ICP-computer program which was set at a level of $2.5 \%$. If the ICP found that the standards and reference solutions diverted by more than $2.5 \%$, it gave a "fail" message and the samples were reanalyzed consequently. The instrumental drift was also corrected. The standards used were multiple element stock standards of a specific concentration $(2,10$ and $50 \mathrm{ppb}$ for $\mathrm{Ni}, \mathrm{Cu}$, and $\mathrm{Pb} ; 50 \mathrm{ppb}$ and $500 \mathrm{ppb}$ for $\mathrm{Zn}$ ).

\subsection{Quality control $(\mathrm{QC})$ and quality assurance $(\mathrm{QA})$ protocols}

In addition to the already mentioned QC measures, standard procedures were always adopted appropriately to maintain QC and QA throughout the analysis. Chemical reagents and procedural blanks were analyzed in parallel to the samples using similar procedures. Calibration curves were optimized by application of quality control standards at each step during analysis. All chemicals and reagents used in analyses were of analytical grade and purchased from Merck (Germany) or BDH (UK) with 99.9\% certified purity.

\subsection{Statistical analysis}

Data were tested for normality and homogeneity of distribution. If required, data were log-transformed prior to applying parametric statistical analyses. The effects of load, ratio and their interactions on soil solution chemistry and heavy metal contents in $\mathrm{HNO}_{3}$ extracts, were tested using a two way-analysis of variance (ANOVA) procedure. A similar analysis was conducted for the effects of liming, ratio and their interactions. This design meant that the data for the $32 \mathrm{kgN}$ treatment were included in both ANOVAs, but it was deemed to be the most effective way of testing the original hypotheses. However, we also compared the soil solution chemistry parameters and heavy metals in soil $\mathrm{HNO}_{3}$ extracts at each ammonium/nitrate ratio between $16 \mathrm{kgN}, 32 \mathrm{kgN}$ and $32 \mathrm{kgN}+$ Lime using one-way ANOVA. In addition, means of soil solution chemistry were tested for significance of differences between $16 \mathrm{kgN}$, $32 \mathrm{kgN}$ and $32 \mathrm{kgN}+$ Lime treatments following one-way ANOVA. Tukey's HSD post-hoc test was used for multiple mean compression techniques, when required. Bivariate correlation plots were developed to study the relationships between soil solution chemistry variables and heavy metal concentrations. All statistical analysis was carried out in SPSS for Windows v. 19 software.

\section{Results}

\subsection{Effects on soil porewater chemistry}

Table 1 shows the two-way ANOVA results concerning the effects of $\mathrm{N}$ load, ratios and their interactions on soil solution chemistry. $\mathrm{N}$ load had significant effects on $\mathrm{Cu}$ concentrations only whereas $\mathrm{N}$ ratios significantly altered $\mathrm{pH}, \mathrm{DOC}$ and $\mathrm{Zn}$ concentrations in porewater. However, interactions between load and ratio were not significant for any porewater chemistry parameters. Twoway ANOVA indicated that effects of liming were significant on $\mathrm{pH}$, $\mathrm{DOC}, \mathrm{NO}_{3}^{-}, \mathrm{Cu}$ and $\mathrm{Zn}$ concentrations, and for those of ratio were significant on $\mathrm{pH}, \mathrm{DOC}, \mathrm{Ni}$ and $\mathrm{Zn}$ (Table 2). Interactions between lime and ratio were significant for $\mathrm{Ni}$ and $\mathrm{Cu}$ concentrations only.

Data about the effects of $16 \mathrm{kgN}, 32 \mathrm{kgN}$ and $32 \mathrm{kgN}+$ Lime on soil solution $\mathrm{pH}, \mathrm{DOC}, \mathrm{NH}_{4}^{+}$and $\mathrm{NO}_{3}^{-}$concentrations at each $\mathrm{NH}_{4}^{+} / \mathrm{NO}_{3}^{-}$ ratio are shown in Fig. 1. Liming significantly increased $\mathrm{pH}$ than $16 \mathrm{kgN}$ and $32 \mathrm{kgN}$ at each $\mathrm{NH}_{4}^{+} / \mathrm{NO}_{3}^{-}$ratio and the highest $\mathrm{pH}$ was noted at $32 \mathrm{kgN}+$ Lime treatment at $1: 1 \mathrm{NH}_{4}^{+} / \mathrm{NO}_{3}^{-}$ratio (Fig. 1a). Effects of $16 \mathrm{kgN}$ and $32 \mathrm{kgN}$ on $\mathrm{pH}$ were generally non-consistent, however, at 1:5 and 1:9 $\mathrm{NH}_{4}^{+} / \mathrm{NO}_{3}^{-}$ratios, $\mathrm{pH}$ increased with $\mathrm{N}$

Table 1

Analysis of variance of effects of $\mathrm{N}$ load, ratio and their interactions on soil solution $\mathrm{pH}, \mathrm{DOC}, \mathrm{NH}_{4}^{+}-\mathrm{N}, \mathrm{NO}_{3}^{-}-\mathrm{N}$ and metal concentrations over the period from June 2009 to September 2010.

\begin{tabular}{llllllllll}
\hline Treatment & & $\mathrm{pH}$ & $\mathrm{DOC}$ & $\mathrm{NH}_{4}^{+}-\mathrm{N}$ & $\mathrm{NO}_{3}^{-}-\mathrm{N}$ & $\mathrm{Ni}$ & $\mathrm{Cu}$ & $\mathrm{Zn}$ & $\mathrm{Pb}$ \\
\hline Load & $\mathrm{F}$ & 0.28 & 1.22 & 1.39 & 1.03 & 0.24 & $\mathbf{3 . 9 6}$ & 3.12 & 1.76 \\
& $P$ & 0.60 & 0.27 & 0.24 & 0.32 & 0.63 & $\mathbf{0 . 0 5}$ & 0.08 & 0.19 \\
& & & & & & & $*$ & & \\
Ratio & $\mathrm{F}$ & $\mathbf{1 2 . 9}$ & $\mathbf{5 . 8 2}$ & 0.66 & 1.23 & 0.70 & 1.85 & $\mathbf{4 . 8 2}$ & 0.15 \\
& $P$ & $\mathbf{0 . 0 0}$ & $\mathbf{0 . 0 0}$ & 0.62 & 0.31 & 0.60 & 0.14 & $\mathbf{0 . 0 0}$ & 0.96 \\
& & $* * *$ & $* *$ & & & & & $* *$ & \\
Load*Ratio & $\mathrm{F}$ & 2.20 & 2.05 & 0.89 & 1.52 & 1.19 & 1.80 & 2.42 & 1.66 \\
& $P$ & 0.09 & 0.10 & 0.48 & 0.21 & 0.33 & 0.15 & 0.06 & 0.18 \\
\hline
\end{tabular}

Bold values indicate level of significance at $* P<0.05, * * P<0.01$ and $* * * P<0.001$. 
Table 2

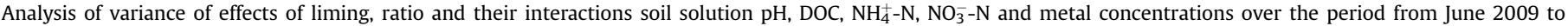
September 2010.

\begin{tabular}{|c|c|c|c|c|c|c|c|c|c|}
\hline Treatment & & $\mathrm{pH}$ & DOC & $\mathrm{NH}_{4}^{+}-\mathrm{N}$ & $\mathrm{NO}_{3}^{-}-\mathrm{N}$ & $\mathrm{Ni}$ & $\mathrm{Cu}$ & $\mathrm{Zn}$ & $\mathrm{Pb}$ \\
\hline \multirow[t]{2}{*}{ Lime } & $\mathrm{F}$ & 35.6 & 6.37 & 0.22 & 5.89 & 1.45 & 8.88 & 8.56 & 0.02 \\
\hline & $P$ & $\begin{array}{c}\mathbf{0 . 0 0} \\
* * *\end{array}$ & $\begin{array}{l}\mathbf{0 . 0 1} \\
*\end{array}$ & 0.64 & $\begin{array}{l}\mathbf{0 . 0 1} \\
*\end{array}$ & 0.23 & $\begin{array}{l}\mathbf{0 . 0 1} \\
*\end{array}$ & $\begin{array}{l}\mathbf{0 . 0 0} \\
* *\end{array}$ & 0.90 \\
\hline \multirow[t]{2}{*}{ Ratio } & $\mathrm{F}$ & 11.3 & 3.19 & 1.40 & 1.48 & 3.22 & 0.45 & 10.0 & 0.41 \\
\hline & $P$ & $\begin{array}{l}\mathbf{0 . 0 0} \\
* * *\end{array}$ & $\begin{array}{l}\mathbf{0 . 0 2} \\
*\end{array}$ & 0.25 & 0.23 & $\begin{array}{l}\mathbf{0 . 0 2} \\
*\end{array}$ & 0.77 & $\begin{array}{l}\mathbf{0 . 0 0} \\
* * *\end{array}$ & 0.80 \\
\hline \multirow[t]{2}{*}{ Lime*Ratio } & $\mathrm{F}$ & 1.76 & 0.74 & 0.08 & 1.96 & 2.79 & 4.09 & 1.05 & 1.41 \\
\hline & $P$ & 0.15 & 0.57 & 0.99 & 0.12 & $\begin{array}{l}0.03 \\
*\end{array}$ & $\begin{array}{l}\mathbf{0 . 0 0} \\
* *\end{array}$ & 0.39 & 0.24 \\
\hline
\end{tabular}

Bold values indicate level of significance at $* P<0.05$, ** $P<0.01$ and $* * * P<0.001$.
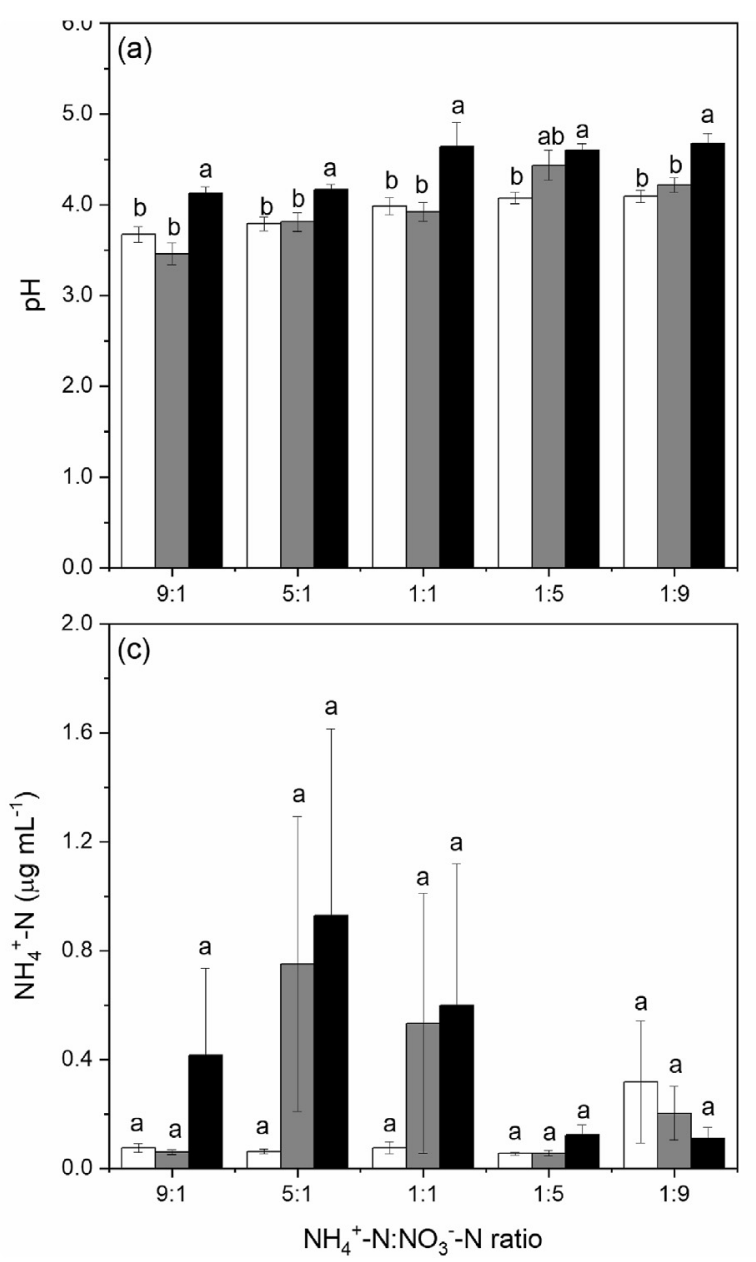
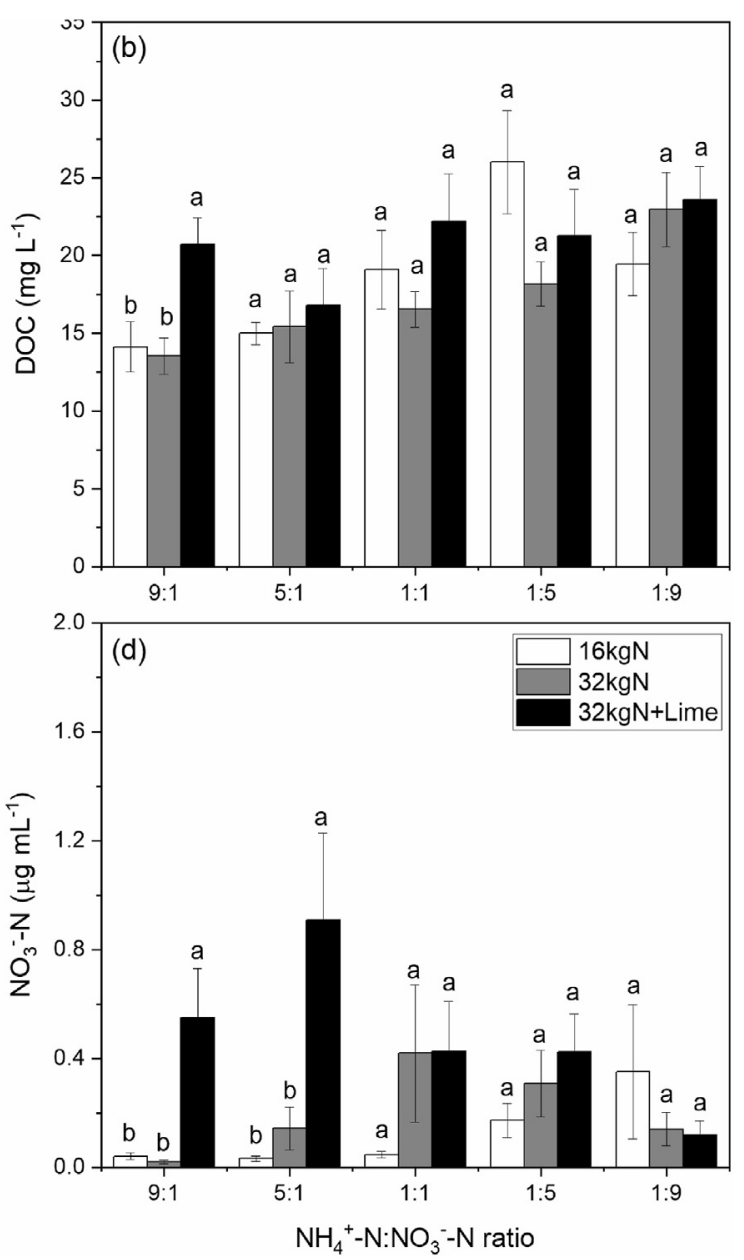

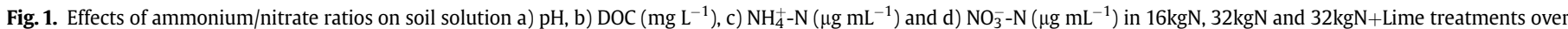

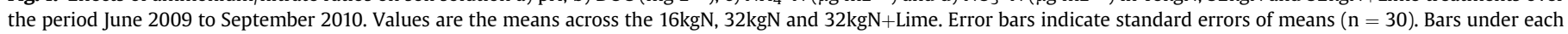
ratio with different letter show significant differences between treatments at $P<0.05$.

load. $\mathrm{pH}$ was low at $\mathrm{NH}_{4}^{+}$dominance and increased when $\mathrm{NO}_{3}^{-}$ dominated $\mathrm{N}$ loads particularly for the $32 \mathrm{kgN}$ and $32 \mathrm{kgN}+$ Lime treatments. Liming also increased DOC concentrations compared to no-limed $\mathrm{N}$ treatments at all $\mathrm{NH}_{4}^{+}$and $\mathrm{NO}_{3}^{-}$ratios except for 1:5 ratio, however, effects were significant at 9:1 ratio only (Fig. 1b). DOC concentrations were higher towards $\mathrm{NO}_{3}^{-}$dominance mainly for $16 \mathrm{kgN}$ and $32 \mathrm{kgN}$ but the trend in effects was not very consistent in $32 \mathrm{kgN}+$ Lime treatment. $\mathrm{NH}_{4}^{+}$concentrations in soil solution increased with $\mathrm{N}$ loads and liming with exceptions to the $1: 9 \mathrm{NH}_{4}^{+}$/ $\mathrm{NO}_{3}^{-}$ratio where reverse effects were found (Fig. 1c). However, due to larger variations in the data, the comparisons between $\mathrm{NH}_{4}^{+} / \mathrm{NO}_{3}^{-}$ ratio were not significant and conclusive. Variations in $\mathrm{NO}_{3}^{-}$concentrations were similar to those observed for $\mathrm{NH}_{4}^{+}$, however, higher $\mathrm{NO}_{3}^{-}$concentrations in $32 \mathrm{kgN}+$ Lime were significantly different than $16 \mathrm{kgN}$ and $32 \mathrm{kgN}$ treatments at 9:1 and 5:1 $\mathrm{NH}_{4}^{+} /$ $\mathrm{NO}_{3}^{-}$ratios (Fig. 1d). Moreover, excluding $1: 9 \mathrm{NH}_{4}^{+} / \mathrm{NO}_{3}^{-}$ratio, $\mathrm{NO}_{3}^{-}$ concentrations were always higher in $32 \mathrm{kgN}+$ Lime treatments.

Differences in Ni concentrations in soil solution between $16 \mathrm{kgN}$, $32 \mathrm{kgN}$ and $32 \mathrm{kgN}+$ Lime treatments at different $\mathrm{NH}_{4}^{+} / \mathrm{NO}_{3}^{-}$ratios were not consistent (Fig. 2a). Ni concentrations in $16 \mathrm{kgN}$ and 


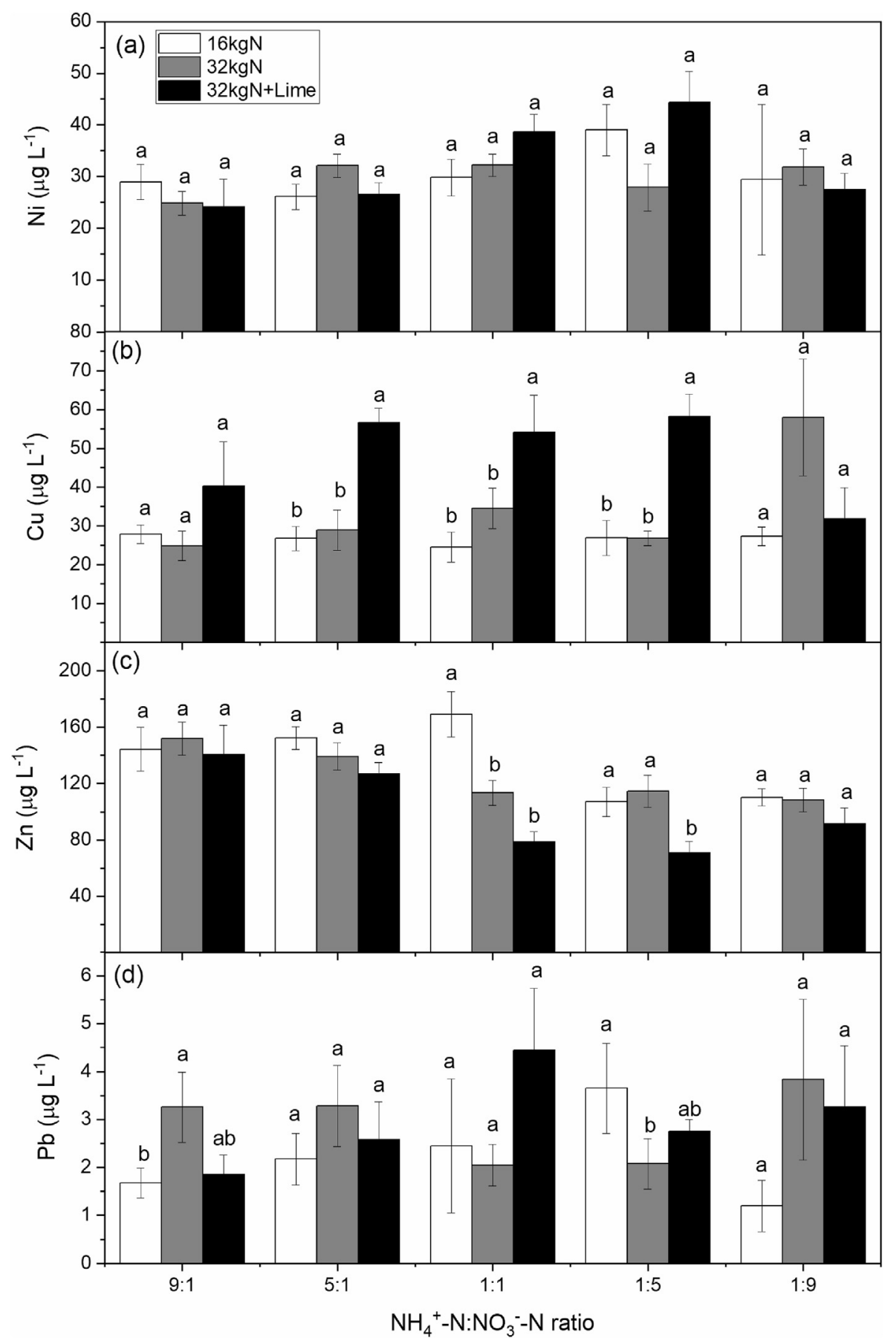

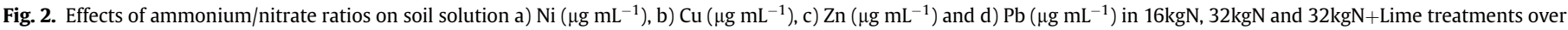

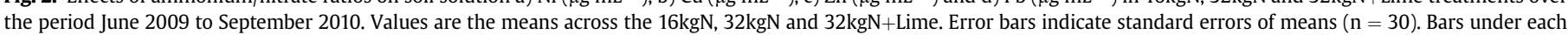
ratio with different letter show significant differences between treatments at $P<0.05$.

$32 \mathrm{kgN}+$ Lime treatments increased with $\mathrm{NO}_{3}^{-}$dominance until 1:5 $\mathrm{NH}_{4}^{+} / \mathrm{NO}_{3}^{-}$ratio. However, the effects of $1: 5$ and $1: 9 \mathrm{NH}_{4}^{+} / \mathrm{NO}_{3}^{-}$ratios were not similar. $\mathrm{Cu}$ concentrations were higher in $32 \mathrm{kgN}+$ Lime than $16 \mathrm{kgN}$ and $32 \mathrm{kgN}$ treatments at 9:1, 5:1,1:1 and $1: 5 \mathrm{NH}_{4}^{+} / \mathrm{NO}_{3}^{-}$ ratios but differed significantly at $5: 1,1: 1$ and $1: 5 \mathrm{NH}_{4}^{+} / \mathrm{NO}_{3}^{-}$ratios only (Fig. 2b). $\mathrm{Cu}$ concentrations also increased with $\mathrm{NO}_{3}^{-}$dominance in $32 \mathrm{kgN}$ treatments in contrast to those in $16 \mathrm{kgN}$ with little variations and values below $30 \mu \mathrm{g} \mathrm{L}^{-1}$ at all $\mathrm{NH}_{4}^{+} / \mathrm{NO}_{3}^{-}$ratios. $\mathrm{Zn}$ concentrations decreased with $\mathrm{NO}_{3}^{-}$dominance and $\mathrm{N}$ load and liming at each $\mathrm{NH}_{4}^{+} / \mathrm{NO}_{3}^{-}$ratio (Fig. 2c). Effects of $\mathrm{N}$ load and liming became more pronounced and significant at $1: 1$ and $1: 5 \mathrm{NH}_{4}^{+} / \mathrm{NO}_{3}^{-}$ ratios. Between $16 \mathrm{kgN}, 32 \mathrm{kgN}$ and $32 \mathrm{kgN}+$ Lime treatments at each $\mathrm{NH}_{4}^{+} / \mathrm{NO}_{3}^{-}$ratio, $32 \mathrm{kgN}$ + Lime always had low $\mathrm{Zn}$ concentrations in soil solution. Concentrations of $\mathrm{Pb}$ showed varied influence of $16 \mathrm{kgN}, 32 \mathrm{kgN}$ and $32 \mathrm{kgN}+$ Lime, and $\mathrm{NH}_{4}^{+} / \mathrm{NO}_{3}^{-}$ratios (Fig. 2d). At 9:1, 5:1 and $1: 9 \mathrm{NH}_{4}^{+} / \mathrm{NO}_{3}^{-}$ratios, $\mathrm{Pb}$ concentrations in $32 \mathrm{kgN}$ were higher than $16 \mathrm{kgN}$ and $32 \mathrm{kgN}+$ Lime but significantly different at $9: 1 \mathrm{NH}_{4}^{+} / \mathrm{NO}_{3}^{-}$ratio only. For the $16 \mathrm{kgN}$ and $32 \mathrm{kgN}+$ Lime treatment, $\mathrm{NO}_{3}^{-}$dominance increased $\mathrm{Pb}$ concentrations up to $1: 5$ and $1: 1$, respectively. 
Changes in soil solution $\mathrm{pH}, \mathrm{DOC}, \mathrm{NH}_{4}^{+}, \mathrm{NO}_{3}^{-}, \mathrm{Ni}, \mathrm{Cu}, \mathrm{Zn}$ and $\mathrm{Pb}$ averaged over five $\mathrm{NH}_{4}^{+} / \mathrm{NO}_{3}^{-}$ratios between $16 \mathrm{kgN}, 32 \mathrm{kgN}$ and $32 \mathrm{kgN}+$ Lime treatments are shown Fig. $3 \mathrm{pH}$ in $32 \mathrm{kgN}+$ Lime was significantly higher than $16 \mathrm{kgN}$ and $32 \mathrm{kgN}$, however, DOC concentrations varied significantly between $16 \mathrm{kgN}$ and $32 \mathrm{kgN}+$ Lime treatments (Fig. 3a and b). $\mathrm{NH}_{4}^{+}$and $\mathrm{NO}_{3}^{-}$concentrations increased sharply with $\mathrm{N}$ load and liming but only $32 \mathrm{kgN}+$ Lime significantly increased $\mathrm{NO}_{3}^{-}$concentrations (Fig. $3 \mathrm{c}$ and d). Concentrations of $\mathrm{Ni}$, $\mathrm{Cu}$ and $\mathrm{Pb}$ were higher in $32 \mathrm{kgN}+$ Lime treatment and $\mathrm{Zn}$ was the lowest in this treatment (Fig. 3e,f,g,h). Cu concentrations increased
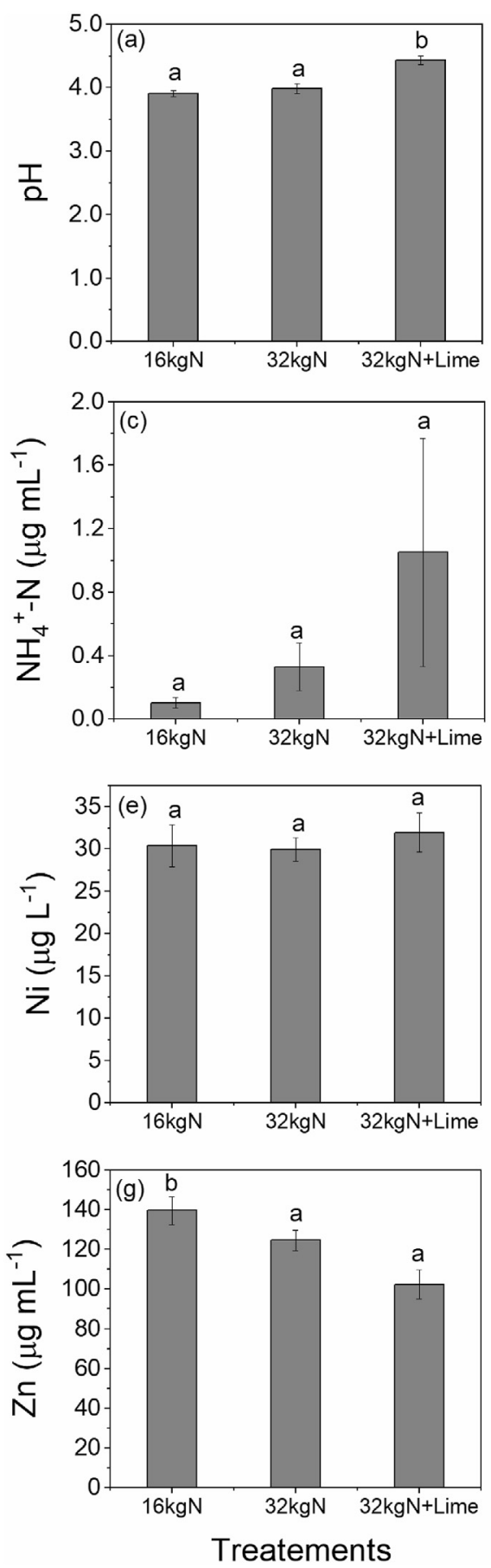

strongly with $\mathrm{N}$ load and liming in contrast to $\mathrm{Zn}$ which followed opposite trend (Fig. $3 \mathrm{f}$ and $\mathrm{g}$ ).

\subsection{Relationship between porewater variables}

Bivariate correlation plots showed that soil solution $\mathrm{pH}$ was significantly positively correlated with DOC $\left(R^{2}=0.52, P<0.01\right.$; Fig. 4a) and $\mathrm{NO}_{3}^{-}$concentrations $\left(R^{2}=0.41, P<0.01\right.$; Fig. 4c). Similar plots were drawn to show the relationships of soil solution $\mathrm{pH}$, DOC, $\mathrm{NH}_{4}^{+}$and $\mathrm{NO}_{3}^{-}$with $\mathrm{Ni}, \mathrm{Cu}, \mathrm{Zn}$ and $\mathrm{Pb}$ concentrations (Fig. 5).
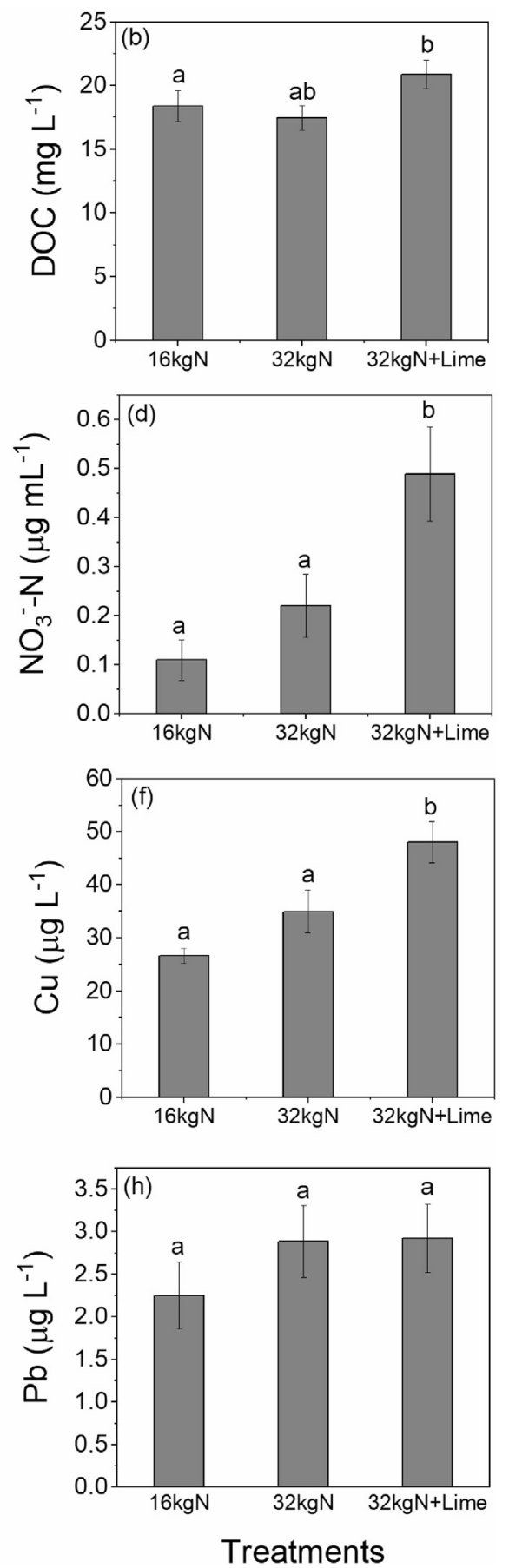

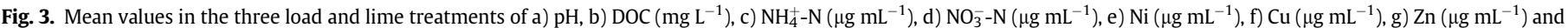

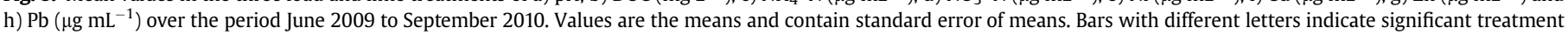
effects at $P<0.05$. 

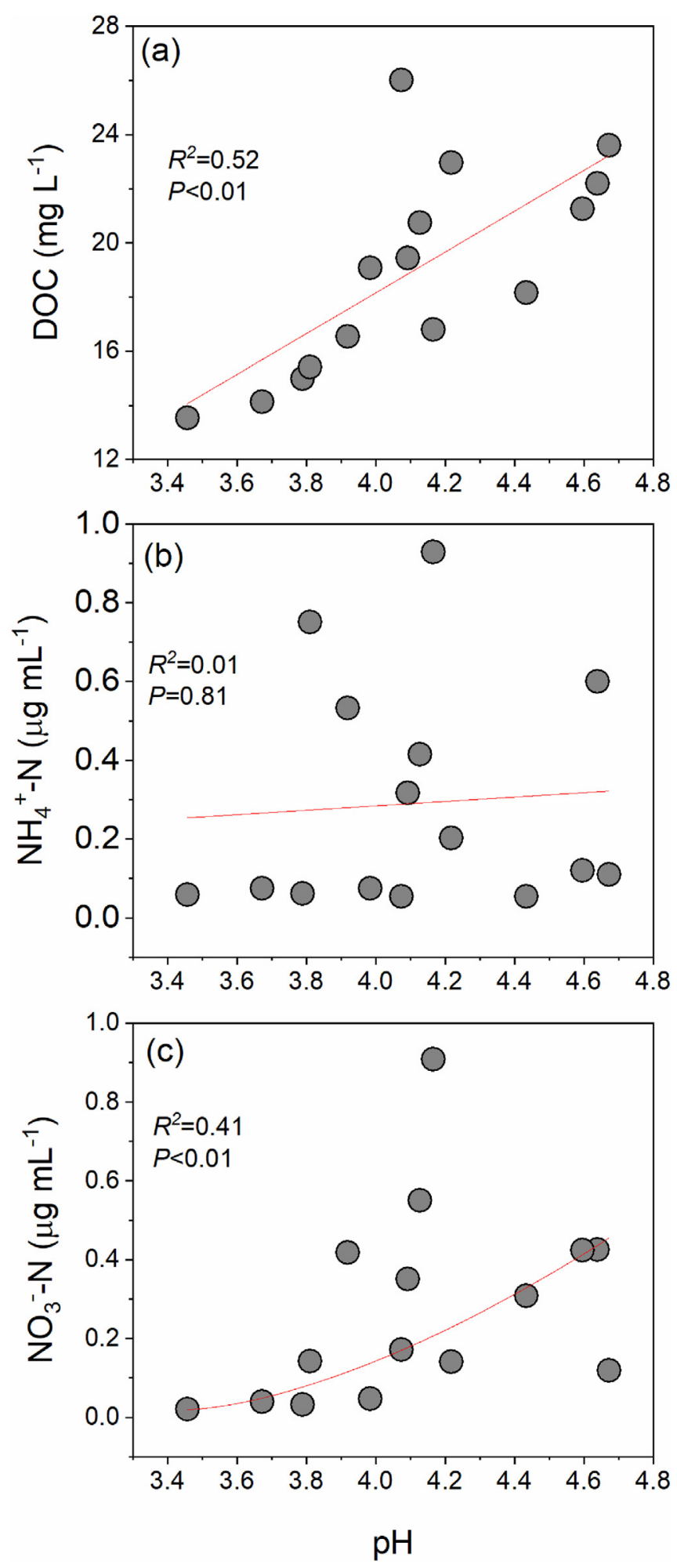

Fig. 4. Relationships of $\mathrm{pH}$ with a) $\mathrm{DOC}\left(\mathrm{mg} \mathrm{L}^{-1}\right)$, b) $\mathrm{NH}_{4}^{-}-\mathrm{N}\left(\mu \mathrm{g} \mathrm{mL}{ }^{-1}\right)$ and c) $\mathrm{NO}_{3}^{-}-\mathrm{N}$ $\left(\mu \mathrm{g} \mathrm{mL}{ }^{-1}\right.$ ) based on 15 different treatments in soil porewater. Data are mean values of 5 ratios within each of the $16 \mathrm{kgN}, 32 \mathrm{kgN}$ and $32 \mathrm{kgN}+$ Lime treatments.

Soil solution $\mathrm{pH}$ correlated significantly positively with $\mathrm{Cu}$ $\left(R^{2}=0.30, P<0.05\right.$; Fig. 5b) and significantly negatively with $\mathrm{Zn}$ $\left(R^{2}=0.66, P<0.001\right.$; Fig. $\left.5 \mathrm{c}\right)$ whereas positive correlation with $\mathrm{Ni}$ (Fig. 5a) and $\mathrm{Pb}$ (Fig. 5d) were not significant. Ni concentrations showed significant positive correlation with DOC $\left(R^{2}=0.26\right.$,
$P<0.05$; Fig. 5e), however, significant negative correlation was observed between $\mathrm{Zn}$ and DOC concentrations $\left(R^{2}=0.41, P<0.05\right.$; Fig. $5 \mathrm{~g}$ ). None of the metals showed significant relationships with $\mathrm{NH}_{4}^{+}$concentrations (Fig. 5i,j,k,l). However, Cu was the only metal showing significant positive correlation with $\mathrm{NO}_{3}^{-}$concentrations $\left(R^{2}=0.38, P<0.05\right.$; Fig. 5n).

\subsection{Soil analysis}

Two-way ANOVA results revealed non-significant effects of ratio, load, liming or their interactions on acid digest concentrations of any of the four metals (Table 3). As evident from ANOVA, the mean data showed no overall patterns in the effects of $16 \mathrm{kgN}$, $32 \mathrm{kgN}$ and $32 \mathrm{kgN}+$ Lime treatments at 9:1 and 1:9 $\mathrm{NH}_{4}^{+} / \mathrm{NO}_{3}^{-}$ratios on heavy metal concentrations in soil digests (Table 4). However, it can be deduced that $\mathrm{Ni}, \mathrm{Cu}$ and $\mathrm{Zn}$ were higher in $32 \mathrm{kgN}$ treatment at 9:1 and $32 \mathrm{kgN}+$ Lime at $1: 9 \mathrm{NH}_{4}^{+} / \mathrm{NO}_{3}^{-}$ratios, respectively but $\mathrm{Pb}$ concentrations, in contrast, were devoid of such patterns.

\section{Discussion}

In this study, the $\mathrm{NH}_{4}^{+} / \mathrm{NO}_{3}^{-}$ratios significantly altered soil solution $\mathrm{pH}$ and with a high $\mathrm{NH}_{4}^{+}$to $\mathrm{NO}_{3}^{-}$ratio, $\mathrm{pH}$ was lower than when $\mathrm{NO}_{3}^{-}$ratios was dominant. This effect of a high $\mathrm{NH}_{4}^{+}$to $\mathrm{NO}_{3}^{-}$ ratio on soil solution $\mathrm{pH}$ has been reported earlier, and is more pronounced under acid conditions because the greater release of $\mathrm{H}^{+}$in soils decrease soil pH (Lucassen et al., 2003; van den Berg et al., 2005). During the nitrification process, two $\mathrm{H}^{+}$ions are release, which can accumulate and significantly reduce the $\mathrm{pH}$ of the soil. The $\mathrm{NH}_{4}^{+}$, therefore, decreases soil $\mathrm{pH}$ to a greater extent due to the nitrification process (Booth et al., 2005). However, at 1:1 $\mathrm{NH}_{4}^{+} / \mathrm{NO}_{3}^{-}$ratios, $\mathrm{pH}$ in $32 \mathrm{KgN}$ was lower than $16 \mathrm{kgN}$, an observation supported by Pilkington et al. (2005) who showed that soil pH decreased with $\mathrm{N}$ load containing balanced $\mathrm{NH}_{4}^{+}$and $\mathrm{NO}_{3}^{-}$. This seems also important observation because in acidic grasslands nitrification process can be sustainably reduced and $\mathrm{NH}_{4}^{+}$can accumulate in soils (Carroll et al., 2003; Riaz et al., 2008; Mian et al., 2009). A recent global meta-analysis also predicted inhibition in nitrification with increase of $\mathrm{NH}_{4}^{+} / \mathrm{NO}_{3}^{-}$ratios in $\mathrm{N}$ deposition which would result in $\mathrm{NH}_{4}^{+}$dominance and reduction in soil $\mathrm{pH}$ (Yan et al., 2019). As reported in our study, soil pH increased with $\mathrm{N}$ load and $\mathrm{NO}_{3}^{-}$dominance in acidic ecosystems (van den Elzen et al., 2018). As expected, liming increased $\mathrm{pH}$, however, this effect was somewhat lower when $\mathrm{NH}_{4}^{+}$dominated in $\mathrm{N}$ load which was also reflected from the significant effects of liming and $\mathrm{NH}_{4}^{+} / \mathrm{NO}_{3}^{-}$ratios on soil solution $\mathrm{pH}$. This was probably because liming was done only once, at the start of the experiment. The higher nitrification rates caused by a high $\mathrm{NH}_{4}^{+} / \mathrm{NO}_{3}^{-}$ratios in deposition, and the fact that $\mathrm{NO}_{3}^{-}$is less likely to be retained in the soils, is likely to result in greater soil acidification, and a greater reduction in the initial effect of the applied lime over time (Lazof et al., 1994; Corre et al., 2003; Ghnaya et al., 2007). Bäckman and Klemedtsson (2003) also reported an increase in $\mathrm{N}$ availability and nitrification in acid coniferous soils under liming and high $\mathrm{N}$ deposition.

Increase in DOC concentration under the influence of $\mathrm{N}$ deposition in our study is consistent with previous findings (e.g. Bragazza et al., 2006; Smemo et al., 2007; Lu et al., 2011). Findlay (2005) also suggested that changes in $\mathrm{pH}$ from $\mathrm{N}$ deposition were potential drivers to explain observed increases in DOC export from ecosystems. The underlying mechanisms remain hypothetical as there are reports of decreased activity of oxidative enzymes in soils receiving $\mathrm{N}$ amendments which would result in greater production of intact phenolic compounds in the bulk DOC pool potentially available for export (Sinsabaugh et al., 2002). One consequence of such a change in carbon degradation patterns in soils would be a 

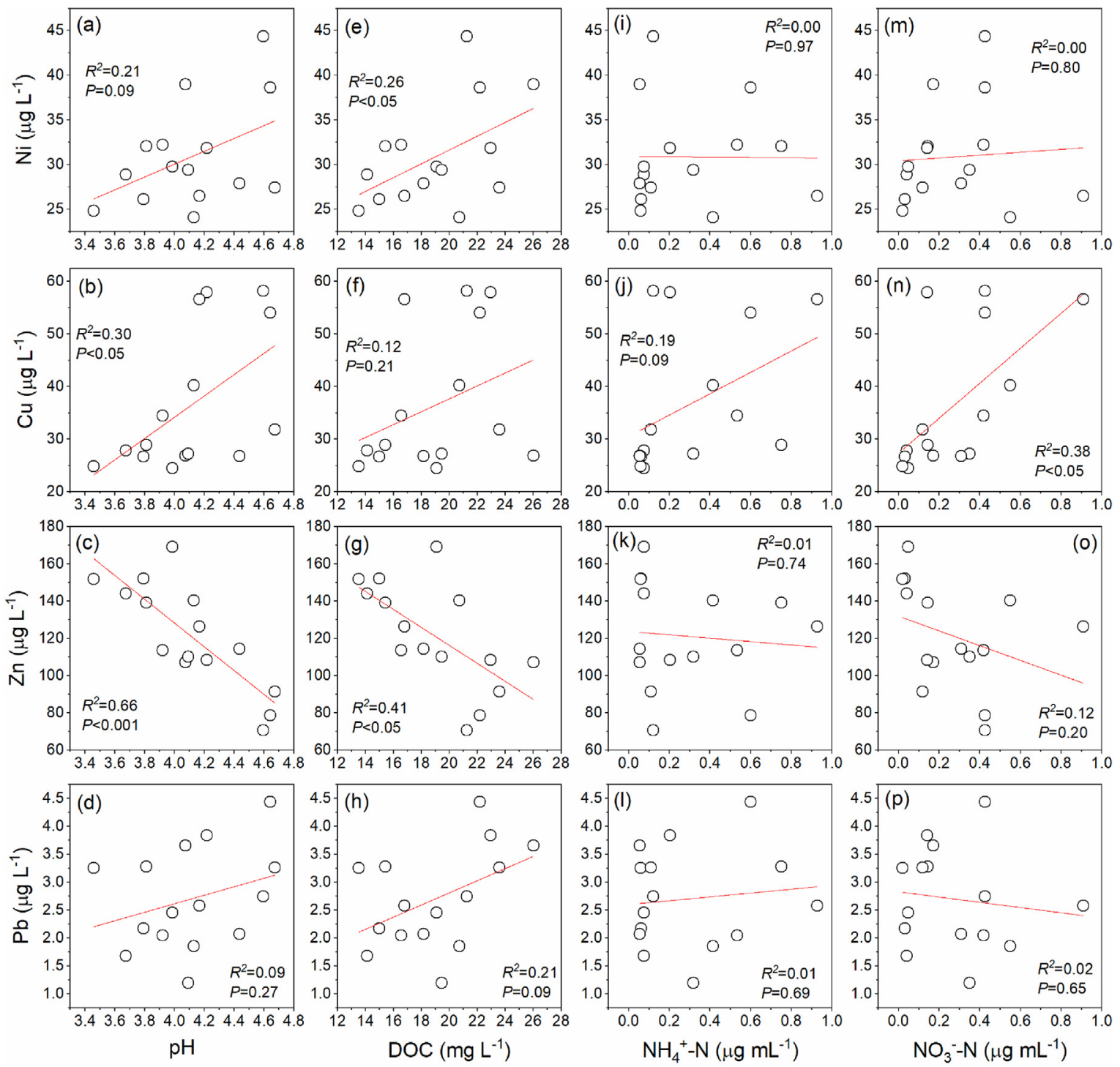

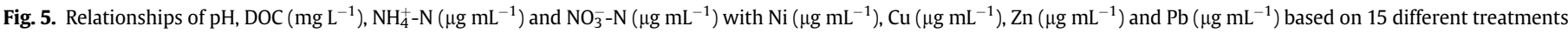
in soil porewater ( 5 ratios within each of the $16 \mathrm{kgN}, 32 \mathrm{kgN}$ and $32 \mathrm{kgN}+$ Lime treatments).

Table 3

Analysis of variance of effects of load, ratio and their interactions, on metal concentrations in $\mathrm{HNO}_{3}$ extracts of soils at the end of the experiment.

\begin{tabular}{llllll}
\hline \multirow{2}{*}{ Factors } & Statistics & $\mathrm{Ni}$ & $\mathrm{Cu}$ & $\mathrm{Zn}$ & $\mathrm{Pb}$ \\
\hline Load & $\mathrm{F}$ & 0.56 & 0.65 & 1.38 & 0.08 \\
\multirow{2}{*}{ Ratio } & $P$ & 0.47 & 0.43 & 0.26 & 0.78 \\
& $\mathrm{~F}$ & 1.96 & 1.97 & 0.68 & 0.17 \\
Load*Ratio & $P$ & 0.18 & 0.18 & 0.42 & 0.69 \\
& $\mathrm{~F}$ & 0.59 & 1.44 & 0.03 & 2.36 \\
Lime & $P$ & 0.45 & 0.25 & 0.86 & 0.14 \\
& $\mathrm{~F}$ & 0.01 & 0.06 & 0.05 & 0.01 \\
Ratio & $P$ & 0.91 & 0.81 & 0.83 & 0.91 \\
& $\mathrm{~F}$ & 0.03 & 0.75 & 0.00 & 0.64 \\
Lime*Ratio & $\mathrm{F}$ & 0.87 & 0.40 & 0.97 & 0.43 \\
& $\mathrm{~F}$ & 2.08 & 3.91 & 0.99 & 1.38 \\
& $P$ & 0.17 & 0.06 & 0.33 & 0.26 \\
\hline
\end{tabular}

decrease in decomposability for this pool of dissolved organic matter. No effects of $\mathrm{N}$ load on DOC concentrations were found in this study despite of significant effects of $\mathrm{NH}_{4}^{+} / \mathrm{NO}_{3}^{-}$ratios on DOC concentrations. While discussing the historical trends of DOC export to rivers in UK, Worrall and Burt (2007) also could not find clear relationships between $\mathrm{N}$ deposition and DOC concentrations whereas air temperature and atmospheric $\mathrm{CO}_{2}$ concentrations seemed relatively more important drivers. Evans et al. (2008) reviewed data from 12 European and North American field $\mathrm{N}$ manipulation experiments and found inconsistent effects of $\mathrm{N}$ load to DOC, however, they reported strong control of $\mathrm{N}$ forms on DOC and showed that $\mathrm{NO}_{3}^{-}$dominance consistently enhanced $\mathrm{DOC}$ in contrast to $\mathrm{NH}_{4}^{+}$which generally decreased DOC. In another study, Sawwicka et al. (2017) used data from six sites from two monitoring networks across UK from 1993 to 2010 and employed MADOC model to predict that DOC concentrations would increase as consequence of $\mathrm{N}$ pollution. Liming increased DOC in our study, an observation consistent with other findings e.g. Curtin and Simillie (1983) noted positive effects of liming on soil organic matter concentrations in soil solution, and Andersson et al. (1994a, 1994b) found the similar effects under laboratory incubation experiment. Both liming and $\mathrm{NH}_{4}^{+} / \mathrm{NO}_{3}^{-}$ratios had significant effects on soil solution $\mathrm{pH}$ and $\mathrm{DOC}$ in our study and, similar, positive correlation 
Table 4

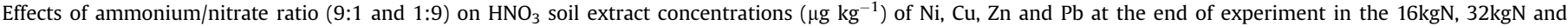
$32 \mathrm{kgN}+$ Lime treatments.

\begin{tabular}{|c|c|c|c|c|c|c|c|c|}
\hline \multirow{2}{*}{ Treatments } & \multicolumn{2}{|l|}{$\mathrm{Ni}\left(\mu \mathrm{g} \mathrm{kg}^{-1}\right)$} & \multicolumn{2}{|l|}{$\mathrm{Cu}\left(\mu \mathrm{g} \mathrm{kg}^{-1}\right)$} & \multicolumn{2}{|l|}{$\mathrm{Zn}\left(\mu \mathrm{g} \mathrm{kg}{ }^{-1}\right)$} & \multicolumn{2}{|l|}{$\mathrm{Pb}\left(\mu \mathrm{g} \mathrm{kg}^{-1}\right)$} \\
\hline & 9:1 ratio & $1: 9$ ratio & $9: 1$ ratio & $1: 9$ ratio & 9:1 ratio & $1: 9$ ratio & 9:1 ratio & $1: 9$ ratio \\
\hline $16 \mathrm{kgN}$ & $27.7(4.72) \mathrm{a}$ & $20.9(3.90) \mathrm{a}$ & $37.2(5.84) \mathrm{a}$ & $35.4(6.14) \mathrm{a}$ & $42.2(2.66) \mathrm{a}$ & $38.3(5.32) a$ & 66.9 (4.89) a & $55.9(5.18) \mathrm{a}$ \\
\hline $32 \mathrm{kgN}$ & $44.1(18.6) \mathrm{a}$ & $20.6(5.84) \mathrm{a}$ & $53.6(12.3)$ a & $32.3(5.41) \mathrm{a}$ & $50.4(9.09)$ a & $44.3(4.86) \mathrm{a}$ & 54.7 (9.20) a & 73.8 (14.7) a \\
\hline $32 \mathrm{kgN}+$ Lime & $27.4(8.47) \mathrm{a}$ & $39.9(12.6) \mathrm{a}$ & $36.9(4.72) \mathrm{a}$ & $45.3(5.65) \mathrm{a}$ & 45.5 (3.85) a & $52.1(6.35) \mathrm{a}$ & $64.9(7.84) \mathrm{a}$ & $61.3(5.88) \mathrm{a}$ \\
\hline
\end{tabular}

Standard errors of means are enclosed in parenthesis. For each metal, values under each ratio columns with different letters differ significantly at $P<0.05$.

was found between soil solution $\mathrm{pH}$ and $\mathrm{DOC}$ which explained the increase in DOC concentrations along the $\mathrm{NO}_{3}^{-}$dominance in $\mathrm{N}$ load. This also signified the negative effects of acidity on DOC production when $\mathrm{NH}_{4}^{+}$dominated $\mathrm{N}$ load. Changes in soil solution $\mathrm{pH}$ is the fundamental mechanism linked to increase in DOC concentrations after liming and N deposition (bAndersson et al., 1994b; Wang et al., 2016). Therefore, effects of rising $\mathrm{pH}$ and declining ionic strength on DOC solubility could have been potentially dominant mechanisms.

The soil solution $\mathrm{pH}$ readily affects chemistry of metals in soils, which influences the availability and plant uptake of micronutrients. Hence, it is clear that both the complexing capacity of organic acids and low $\mathrm{pH}$ are major factors related to mobilization of metals in soil (Kashem and Singh, 2001; McCauley et al., 2009). Therefore, soil solution $\mathrm{pH}$ determines mobility and bioavailability of heavy metals including $\mathrm{Zn}, \mathrm{Ni}, \mathrm{Cu}$ and $\mathrm{Pb}$, and decrease in soil $\mathrm{pH}$ dramatically transform heavy metals from solid-phase to soil solution (Badawy et al., 2002; Zhao et al., 2010). In our study, for example, Zn partitioning between soil and soil solution was governed primarily by changes in $\mathrm{pH}$ because we found higher $\mathrm{Zn}$ concentrations at lower $\mathrm{pH}$ values that were recorded when $\mathrm{NH}_{4}^{+}$ dominated in $\mathrm{N}$ load. However, the addition of lime decreased $\mathrm{Zn}$ concentrations in porewater due to less solubilization at higher $\mathrm{pH}$ values. In addition, increased $\mathrm{NH}_{4}^{+}$deposition affects the concentration of essential base cations such as $\mathrm{K}^{+}, \mathrm{Mg}^{2+}$ and $\mathrm{Ca}^{2+}$ by exchanging them on the cation exchange sites on the soil and, at low $\mathrm{pH}$, by decreasing base cation uptake by plants (Boxman et al., 1991; Gloser and Gloser, 2000), and similar effects may apply to Zn in soil solution in our study. Leaching of base cations under the influence of $\mathrm{N}$ deposition is frequently reported, especially when $\mathrm{NH}_{4}^{+}$dominates deposition load (e.g. White and Cresser, 1998; Horswill et al., 2008; Cusack et al., 2016). Nickel, in contrast, showed no significant effect of $\mathrm{N}$ load but $\mathrm{NH}_{4}^{+} / \mathrm{NO}_{3}^{-}$ratios and, lime and $\mathrm{NH}_{4}^{+} / \mathrm{NO}_{3}^{-}$ratio interactions significantly affected Ni concentrations. There was also significant positive association of $\mathrm{Ni}$ with DOC and positive but non-significant correlation with $\mathrm{pH}$. Similar to our observation, Rinklebe et al. (2016) found strong correlations between $\mathrm{Ni}$ and DOC concentration and predicted this association due to Ni-DOC complexes formation in serpentine-enriched fluvisol. As evident from significant $\mathrm{N}$ load, lime and, lime and $\mathrm{NH}_{4}^{+} / \mathrm{NO}_{3}^{-}$ ratio interactions effects on $\mathrm{Cu}$ concentrations and also positive but weak and non-significant correlations between $\mathrm{Cu}$ and DOC, $\mathrm{Cu}$ has been suggested to make stronger complexes with organic ligands compared to any other heavy metal (Lehman and Mills, 1994; Milne et al., 2003; Cuske et al., 2017). Moreover, Cu concentrations in soil solution in this study were significantly higher in cores when $\mathrm{NO}_{3}^{-}$ dominant deposition load and at higher concentrations of DOC in the $16 \mathrm{kgN}, 32 \mathrm{kgN}$ and $32 \mathrm{kgN}+$ Lime treatments. However, the same effects of DOC were not observed for Pb concentrations, for which no significant effects of $\mathrm{N}$ load, liming or $\mathrm{NH}_{4}^{+} / \mathrm{NO}_{3}^{-}$ratios were found, despite of the positive insignificant correlations between $\mathrm{DOC}$ and $\mathrm{Pb}$ concentrations. This could be due to relatively low concentrations of both $\mathrm{Pb}$ and $\mathrm{DOC}$ in this experiment. We found that varying the $\mathrm{NH}_{4}^{+} / \mathrm{NO}_{3}^{-}$ratios significantly affected both $\mathrm{pH}$ and
DOC concentrations in soil solution, however, these changes were not always associated with strong changes in heavy metal concentrations.

Analysis of the heavy metals data in $\mathrm{HNO}_{3}$ soil extracts showed some patterns but no significant effects of $\mathrm{N}$ load, $\mathrm{NH}_{4}^{+} / \mathrm{NO}_{3}^{-}$ratios, liming and their interactions. Therefore, we deduced that any treatment-related variations in soil metal concentrations had no significance for the interpretation of the soil solution data.

\section{Conclusions}

Our study showed that soil solution $\mathrm{pH}$ and DOC were lower when $\mathrm{NH}_{4}^{+}$dominated the $\mathrm{N}$ load and increased with $\mathrm{N}$ load and lime, and both $\mathrm{pH}$ and $\mathrm{DOC}$ increased with $\mathrm{NO}_{3}^{-}$dominance and liming. pH and DOC also showed significant positive correlation. Application of base cations in the form of lime $\left(\mathrm{Ca}^{2+}\right.$ and $\left.\mathrm{Mg}^{2+}\right)$ resulted in larger increase of DOC leaching in those treatments where $\mathrm{NH}_{4}^{+}$was dominant and liming generally increased both $\mathrm{pH}$ and DOC in soil soltuion. $\mathrm{Zn}$ concentrations were significantly higher when $\mathrm{NH}_{4}^{+}$dominated and without liming suggesting $\mathrm{pH}$ as the major driver controlling its soil solution concentrations and evidence was further supported by the negative relationship between $\mathrm{Zn}$ and DOC. However, $\mathrm{Cu}$ concentrations were significantly higher when $\mathrm{NO}_{3}^{-}$dominated $\mathrm{N}$ load and with liming, and a strong association was observed with DOC in soil soltuion. Metal mobilization of $\mathrm{Ni}, \mathrm{Cu}$ and $\mathrm{Pb}$ was driven by $\mathrm{DOC}$ concentrations and, therefore, found to be higher in cores where $\mathrm{NO}_{3}^{-}$was dominant in deposition load. On the other side, low pH and high $\mathrm{NH}_{4}^{+}$in $\mathrm{N}$ load were related to $\mathrm{Zn}$ mobility. Mean values in three $\mathrm{N}$ load and liming treatments showed their positive effects on soil solution $\mathrm{pH}, \mathrm{DOC}$, $\mathrm{Ni}, \mathrm{Cu}$ and $\mathrm{Pb}$ whereas $\mathrm{Zn}$ concentrations decreased at higher $\mathrm{N}$ load and liming. However, despite some patterns in the effects of $\mathrm{N}$ loads and liming on heavy metal concentrations in soil $\mathrm{HNO}_{3}$ extracts, none of them showed clear and significant effects. Our study concludes that both oxidized and reduced $\mathrm{N}$ species in deposition load could mobilize heavy metals in soil solution in low $\mathrm{N}$ input ecosystems and, liming ecosystems with historical $\mathrm{N}$ deposition, could further exacerbate the risk of heavy metal pollution of surface and groundwater resources. Therefore, the effects of $\mathrm{N}$ load along oxidized and reduced forms in deposition are required to be applied in a wider research programme that includes sites with high accumulated loads of metals so the impacts of $\mathrm{N}$ deposition forms are better quantified through soil solution partitioning models.

\section{Declaration of competing interest}

The authors declare no conflict of interest.

\section{CRediT authorship contribution statement}

Afia Zia: Conceptualization, Methodology, Formal analysis, Investigation, Writing - original draft, Visualization, Writing - 
review \& editing, Funding acquisition. Leon van den Berg: Methodology, Resources, Writing - review \& editing. Muhammad Riaz: Formal analysis, Visualization, Writing - original draft, Writing review \& editing. Muhammad Arif: Writing - review \& editing. Dania Zia: Visualization, Writing - review \& editing. Shawana J. Khan: Visualization, Writing - review \& editing. Muhammad Nauman Ahmad: Visualization, Writing - review \& editing. Attaullah: Writing - review \& editing. Mike Ahsmore: Conceptualization, Resources, Supervision, Project administration.

\section{Acknowledgements}

This work is part of the PhD thesis of Afia Zia at The University of York, UK. Afia Zia received financial support from Higher Education Commission of Pakistan and The University of Agriculture Peshawar, Pakistan under Faculty Development Program.

\section{Appendix A. Supplementary data}

Supplementary data to this article can be found online at https://doi.org/10.1016/j.envpol.2020.114981.

\section{References}

Alexander, E.B., 2004. Varieties of ultramafic soil formation, plant cover and productivity. In: Boyd, R.S., Baker, A.J.M., Proctor, J. (Eds.), Ultramafic Rocks: Their Soils, Vegetation and Fauna. Proceedings of the 4th International Conference on Serpentine Ecology. Science Reviews, St. Albans, Herts, UK, pp. 9-17.

Andersson, S., Nilsson, S.I., Saetere, P., 1994a. Leaching of dissolved organic carbon (DOC) and dissolved organic nitrogen (DON) in mor humus as affected by temperature and pH. Soil Biol. Biochem. 32, 1-10.

Andersson, S., Valeur, I., Nilsson, S.I., 1994b. Influence of lime on soil respiration, leaching of DOC, and C/S relationships in the mor humus of a haplic podzol. Environ. Int. 20, 81-88.

Aneja, V.P., Roelle, P.A., Murray, G.C., Southerland, J., Erisman, J.W., Fowler, D., Asman, W.A.H., Patni, N., 2001. Atmospheric nitrogen compounds II: emissions, transport, transformation, deposition and assessment. Atmos. Environ. 35, 1903-1911.

Bäckman, J.S.K., Klemedtsson, A.K., 2003. Increased nitrification in acid coniferous forest soil due to high nitrogen deposition and liming. Scand. J. For. Res. 18, 514-524.

Badawy, H., Helal, M.I.D., Chaudri, A.M., Lawlor, K., McGrath, S.P., 2002. Soil solidphase controls lead activity in soil solution. J. Environ. Qual. 31, 162-167.

Binkley, D., Hogberg, P., 2016. Tamm review: revisiting the influence of nitrogen deposition on Swedish forests. For. Ecol. Manag. 368, 222-239.

Bobbink, R., Tomassen, H., Weijters, M., van den Berg, L., Strengbom, J., Braun, S., Nordin, A., Schütz, K., Hettelingh, J.P., 2015. Effects and empirical critical loads of nitrogen for Europe. In: de Vries, W., Hettelingh, J.P., Posch, M. (Eds.), Critical Loads and Dynamic Risk Assessments. Springer Netherlands, pp. 85-127.

Booth, M.S., Stark, J.M., Rastetter, E., 2005. Controls on nitrogen cycling in terrestrial ecosystems: a synthetic analysis of literature data. Ecol. Monogr. 75, 139-157.

Boxman, A.W., Krabbendam, H., Bellemakers, M.J.S., Roelofs, J.G.M., 1991. Effects of ammonium and aluminium on the development and nutrition of Pinus nigra in hydroculture. Environ. Pollut. 73, 119-136.

Bragazza, L., Freeman, C., Jones, T., Rydin, H., Limpens, J., Fenner, N., Ellis, T., Gerdol, R., Hájek, M., Hájek, T., Iacumin, P., Kutnar, L., Tahvanainen, T., Toberman, H., 2006. Atmospheric nitrogen deposition promotes carbon loss from peat bogs. Proc. Natl. Acad. Sci. Unit. States Am. 103, 19386-19389.

Carroll, J.A., Caporn, S.J.M., Johnson, D., Morecroft, M.D., Lee, J.A., 2003. The interactions between plant growth, vegetation structure and soil processes in semi-natural acidic and calcareous grasslands receiving long-term inputs of simulated pollutant nitrogen deposition. Environ. Pollut. 121, 363-346.

Chen, H., Gurmesa, G.A., Zhang, W., Zhu, X.M., Zheng, M.H., Mao, Q.G., Zhang, T., Mo, J.M., 2016. Nitrogen saturation in humid tropical forests after 6 years of nitrogen and phosphorus addition: hypothesis testing. Funct. Ecol. 30, 305-313.

Corre, M.D., Beese, F.O., Brumme, R., 2003. Soil nitrogen cycle in high nitrogen deposition forest: changes under nitrogen saturation and liming. Ecol. Appl. 13, 287-298.

Curtin, D., Simillie, G.W., 1983. Soil solution composition as affected by liming and incubation. Soil Sci. Soc. Am. J. 47, 701-707.

Cusack, D.F., Macy, J., McDowell, W.H., 2016. Nitrogen additions mobilize soil base cations in two tropical forests. Biogeochemistry 128, 67-88.

Cuske, M., Karczewska, A., Galka, B., 2017. Speciation of $\mathrm{Cu}, \mathrm{Zn}$, and $\mathrm{Pb}$ in soil solutions extracted from strongly polluted soils treated with organic materials. Pol. J. Environ. Stud. 26, 567-575.

Decina, S.M., Hutyra, L.R., Templer, P.H., 2020. Hotspots of nitrogen deposition in the world's urban areas: a global data synthesis. Front. Ecol. Environ. 18, 92-100.
EEA, 2014a. NEC Directive Status Report 2013, Reporting by the Member States under Directive 2001/81/EC of the European Parliament and of the Council of 23 October 2001 on National Emission Ceilings for Certain Atmospheric Pollutants. EEA Technical report No 10/2014, European Environment Agency. Available at: http://www.eea.europa.eu/publications/nec-directive-statusreport-2013. (Accessed 17 June 2014).

Erisman, J.W., Leach, A., Bleeker, A., Atwell, B., Cattaneo, L., Galloway, J., 2018. An integrated approach to a nitrogen use efficiency (NUE) indicator for the food production-consumption chain. Sustainability 10, 925.

Evans, C.D., Goodale, C.L., Caporn, S.J.M., Dise, N.B., Emmett, B.A., Fernandez, I.J., Field, C.D., Findlay, S.E.G., Lovett, G.M., Meesenburg, H., Moldan, F., Sheppard, L.J., 2008. Does elevated nitrogen deposition or ecosystem recovery from acidification drive increased dissolved organic carbon loss from upland soil? A review of evidence from field nitrogen addition experiments. Biogeochemistry $91,13-35$.

Findlay, S.E.G., 2005. Increased carbon transport in the Hudson River: unexpected consequence of nitrogen deposition? Front. Ecol. Environ. 3, 133-137.

Fleischer, K., Wårlind, D., van den der Molen, M.K., Rebel, K.T., Arneth, A. Erisman, J.W., Wassen, M.J., Smith, B., Gough, C.M., Margolis, H.A., Cescatti, A. Montagnani, L., Arain, A., Dolman, A.J., 2015. Low historical nitrogen deposition effect on carbon sequestration in the boreal zone. J. Geophys. Res.-Biogeo. 120, 2542-2561.

Fowler, D., Muller, J.B.A., Sheppard, L.J., 2004a. The GaNE programme in a global perspective. Water, Air, Soil Pollut. 4, 3-8.

Fowler, D., O'Donoghue, M., Muller, J.B.A., Smith, R.I., Dragosits, U., Skiba, U., Sutton, M.A., Brimblecombe, P., 2004b. A chronology of nitrogen deposition in the UK between 1900 and 2000. Water, Air Soil Pollut 4, 9-23.

Galloway, J.N., Schlesinger, W.H., Levy II, H., Michaels, A., Schnoor, J.L., 1995. Nitrogen fixation: atmospheric enhancement-environmental response. Globa Biogeochem. Cycles 9, 235-252.

Ghnaya, T., Slama, I., Messedi, D., Grignon, C., Ghorbel, M.H., Abdelly, C., 2007. Effects of $\mathrm{Cd} 2 \mathrm{p}$ on $\mathrm{Kp}, \mathrm{Ca} 2 \mathrm{p}$ and $\mathrm{N}$ uptake in two halophytes Sesuvium portulacastrum and Mesembryanthemum crystallinum: consequences on growth. Chemosphere 67, 72-79.

Gloser, V., Gloser, J., 2000. Nitrogen and base cation uptake in seedlings of Ace pseudoplatanus and Calamagrostis villosa exposed to an acidified environment. Plant Soil 226, 71-77.

Goulding, K.W.T., 2016. Soil acidification and the importance of liming agricultura soils with particular reference to the United Kingdom. Soil Use Manag. 32, 390-399.

Horswill, P., O’Sullivan, O., Phoenix, G.K., Lee, J.A., Leake, J.R., 2008. Base cation depletion, eutrophication and acidification of species-rich grasslands in response to long-term simulated nitrogen deposition. Environ. Pollut. 155 336-349.

Hu, Y., Huang, Y., Su, J., Gao, Z., Li, S., Nan, Z., 2018. Temporal changes of metal bioavailability and extracellular enzyme activities in relation to afforestation of highly contaminated calcareous soil. Sci. Total Environ. 622-623, 1056-1066.

Huang, Y.M., Kang, R.H., Mulder, J., Zhang, T., Duan, L., 2015. Nitrogen saturation, soil acidification, and ecological effects in a subtropical pine forest on acid soil in southwest China. J. Geophys. Res.-Biogeo. 120, 2457-2472.

Jiang, J., Wang, Y.P., Yu, M., Li, K., Shao, Y., Yan, J., 2016. Responses of soil buffering capacity to acid treatment in three typical subtropical forests. Sci. Total Environ. 563-564, 1068-1077.

Jones, D.L., 1998. Organic acids in the rhizosphere - a critical review. Plant Soil 205 25-44.

Kaiser, K., 2001. Dissolved organic phosphorus and sulphur as influenced by sorptive interactions with mineral subsoil horizons. Eur. J. Soil Sci. 52, 489-493.

Kashem, M.A., Singh, B.R., 2001. Metal availability in contaminated soils: I. Effects o flooding and organic matter on changes in $\mathrm{Eh}, \mathrm{pH}$ and solubility of $\mathrm{Cd}, \mathrm{Ni}$ and Zn. Nutrient Cycl. Agroecosyst. 61, 247-255.

Lazof, D.B., Rincon, M., Rufty, T.W., MacKown, C.T., Carter, T.E., 1994. Aluminium accumulation and associated effects on ${ }^{15} \mathrm{NO}_{3}$ influx in roots of two soybean genotypes differing in Al tolerance. Plant Soil 164, 291-297.

Lehman, R.M., Mills, A.L., 1994. Field evidence for copper mobilization by dissolved organic matter. Water Res. 28, 2487-2497.

Li, Y., Niu, S.L., Yu, G.R., 2016. Aggravated phosphorus limitation on biomass production under increasing nitrogen loading: a meta-analysis. Global Change Biol. 22, 934-943.

Lu, M., Zhou, X., Luo, Y., Yang, Y., Fang, C, Chen, J. Li, B., 2011. Minor stimulation of soil carbon storage by nitrogen addition: a meta-analysis. Agric. Ecosyst. Environ. 140, 234-244.

Lucassen, M., Schmidt, A., Pörtner, H.O., 2003. Cold induced mitochondrial proliferation in Zoarces viviparus: changes in enzyme activities and mRNA levels. Am. J. Physiol. 258, 1410-1420.

Maas, R., Grennfelt, P. (Eds.), 2016. Towards Cleaner Air. Scientific Assessment Report 2016. EMEP Steering Body and Working Group on Effects of the Convention on Long-Range Transboundary Air Pollution. Oslo. xx+50pp.

Matejko, M., Dore, A.J., Hall, J., Dore, C.J., Błaś, M., Kryza, M., Smith, R., Fowler, D. 2009. The influence of long term trends in pollutant emissions on deposition of sulphur and nitrogen and exceedance of critical loads in the United Kingdom. Environ. Sci. Pol. 12, 882-896.

McCauley, A., Jones, C., Jacobsen, J., 2009. Soil pH and Organic Matter Nutrient Management Modules 8, \#4449-8. MontanaState University Extension Service, Bozeman, Montana, pp. 1-12.

Mian, I.A., Riaz, M., Cresser, M.S., 2009. The importance of ammonium mobility in 
nitrogen-impacted unfertilized grasslands: a critical reassessment. Environ. Pollut. 157, 1287-1293.

Milne, C.J., Kinniburgh, D.G., van Riemsdijk, W.H., Tipping, E., 2003. Generic NICADonnan model parameters for metalion binding by humic substances. Environ. Sci. Technol. 37, 958-971.

Oenema, O., Bleeker, A., Braathen, N.A., Budňáková, K.B., Čermák, P., Geupel, M. Hicks, K., Hoft, R., Kozlova, N., Leip, A., Spranger, T., Valli, L., Velthof, G. Winiwarter, W., 2011. Nitrogen in current European policies. In: Sutton, M.A., Howard, C.M., Erisman, J.W., Billen, G., Bleeker, A., Grennfelt, P., van Grinsven, H., Grizzetti, B. (Eds.), European Nitrogen Assessment (ENA). Cambridge University Press, UK, pp. 62-81.

Pilkington, M.G., Capron, S.J.M., Carroll, J.A., Cresswell, N., Lee, J.A., Ashenden, T.W., Brittain, S.A., Reynolds, B., Emmet, B.A., 2005. Effects of increased deposition of atmospheric nitrogen on an upland moor: leaching of $\mathrm{N}$ species and soil solution chemistry. Environ. Pollut. 135, 29-40.

Riaz, M., Mian, I.A., Cresser, M.S., 2008. Extent and causes of 3D spatial variations in potential $\mathrm{N}$ mineralization and the risk of ammonium and nitrate leaching from an N-impacted permanent grassland near York, UK. Environ. Pollut. 156, 1075-1082.

Riaz, M., Mian, I.A., Cresser, M.S., 2009. Controls on inorganic N species transformations and potential leaching in freely drained sub-soils of heavily $\mathrm{N}$ impacted acid grassland. Biogeochemistry 92, 263-279.

Rinklebe, J., Antić-Mladenović, S., Frohne, T., Stärk, H.J., Tomić, Z., Ličina, V., 2016. Nickel in a serpentine-enriched Fluvisol: redox affected dynamics and binding forms. Geoderma 263, 203-214.

RoTAP, 2012. Review of Transboundary Air Pollution. 'Acidification, Eutrophication, Ground-Level Ozone and Heavy Metals in the UK'. Available at: http://www. rotap.ceh.ac.uk/. (Accessed 21 March 2009).

Sawwicka, K., Rowe, E.C., Evans, C.D., Monteith, D.T., Vanguelova, E.I., Wade, A.J., Clark, J.M., 2017. Modelling impacts of atmospheric deposition and temperature on long-term DOC trends. Sci. Total Environ. 578, 323-336.

Sheppard, L.J., Crossley, A., Leith, I.D., Hargreaves, K.J., Carfrae, J.A., van Dijk, N., Cape, J.N., Sleep, D., Fowler, D., Raven, J.A., 2004. An automated wet deposition system to compare the effects of reduced and oxidised $\mathrm{n}$ on ombrotrophic bog species: practical considerations. Water, Air, Soil Pollut. 4, 197-205.

Sinsabaugh, R.L., Carreiro, M.M., Repert, D.A., 2002. Allocation of extracellular enzymatic activity in relation to litter composition, $\mathrm{N}$ deposition, and mass loss. Biogeochemistry 60, 1-24.

Smemo, K.A., Zak, D.R., Pregtizer, K.S., Burton, A.J., 2007. Characteristics of doc exported from northern hardwood forests receiving chronic experimental $\mathrm{NO}_{3}$ deposition. Ecosystems 10, 369-379.

Stevens, C.J., Dise, N.B., Gowing, D.J., 2009. Regional trends in soil acidification and exchangeable metal concentrations in relation to acid deposition rates. Environ.
Pollut. 157, 313-319

Stevens, C.J., Manning, P., van den Berg, L.J.L., de Graaf, M.C.C., Wamelink, G.W.W., Boxman, A.W., Bleeker, A., Vergeer, P., Arroniz-Crespo, M., Limpens, J., Lamers, L.P.M., Bobbink, R., Dorland, E., 2011. Ecosystem responses to reduced and oxidised nitrogen inputs in European terrestrial habitats. Environ. Pollut. 159, 665-676.

Tipping, E., Hurley, M.A., 1992. A unifying model of cation binding by humic substances. Geochim. Cosmochim. Acta 56, 3627-3641.

Ussiri, D.A.N., Lal, R., 2013. Global nitrogen cycle. In: Ussiri, D.A.N., Lal, R. (Eds.), Soil Emission of Nitrous Oxide and its Mitigation. Springer, Dordrecht, the Netherlands.

van den Berg, L.J.L., Dorland, E., Vergeer, P., Hart C, M.A., Bobbink, R., Roelofs, J.G.M., 2005. Decline of acid-sensitive plant species in heathland can be attributed to ammonium toxicity in combination with low pH. New Phytol. 166, 551-564.

van den Berg, L.J.L., Jones, L., Sheppard, L.J., Smart, S.M., Bobbink, R., Dise, N.B., Ahsmore, M., 2016. Evidence for differential effects of reduced and oxidised nitrogen deposition on vegetation independent of nitrogen load. Environ. Pollut. 208, 890-897.

van den Elzen, van den Berg, L.J.L., van der Weijden, B., Fritz, C., Sheppard, L.J., Lamers, L.P.M., 2018. Effects of airborne ammonium and nitrate pollution strongly differ in peat bogs, but symbiotic nitrogen fixation remains unaffected. Sci. Total Environ. 610-611, 732-740.

Wang, X., Tang, C., Baldock, J.A., Butterly, C.R., Gazey, C., 2016. Long-term effect of lime application on the chemical composition of soil organic carbon in acid soils varying in texture and liming history. Biol. Fertil. Soils 52, 295-306.

White, C.C., Cresser, M.S., 1998. Effects of enhanced N deposition as (NH4)2SO4 and HNO3 on base cation leaching from podzol microcosms. Environ. Pollut. 102, 463-469.

Worrall, F., Burt, T.P., 2007. Trends in DOC concentration in great britain. J. Hydrol, $346,81-92$.

Yan, L., Xu, X., Xia, J., 2019. Different impacts of external ammonium and nitrate addition on plant growth in terrestrial ecosystems: a meta-analysis. Sci. Total Environ. 686, 1010-1018.

Yang, Y., He, Z., Wang, Y., Fan, J., Liang, Z., Stoffella, P.J., 2013. Dissolved organic matter in relation to nutrients ( $\mathrm{N}$ and $\mathrm{P}$ ) and heavy metals in surface runoff water as affected by temporal variation and land uses - a case study from Indian River Area, south Florida, USA. Agric. Water Manag. 118, 38-49.

Zhao, K.L., Liu, X.M., Xu, J.M., Selim, H.M., 2010. Heavy metal contaminations in a soil-rice system: identification of spatial dependence in relation to soil properties of paddy fields. J. Hazard Mater. 181, 778-787.

Zia, A., van den Berg, L., Ahmad, M.N., Riaz, M., Zia, D., Ashmore, M., 2018. Controls on accumulation and soil solution partitioning of heavy metals across upland sites in United Kingdom (UK). J. Environ. Manag. 222, 260-267. 